НАУКОВИЙ ВІСНИК

T.

Cientific messegger of Livi National University
Veterinary Meedicine and Biotechnologies

now

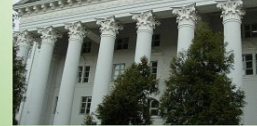



Toм 21 № 91

2019

Науковий вісник Дьвівського національного університету ветеринарної медицини та біотехнологій імені С.3. Гжицького. Серія: Сільськогосподарські науки

Scientific Messenger of Lviv National University of Veterinary Medicine and Biotechnologies. Series: Agricultural sciences

UDC 69.034.93:631.2

\title{
Features of waterproofing of agricultural buildings and structures
}

\author{
R.M. Myniv \\ Stepan Gzhytskyi National University of Veterinary Medicine and Biotechnologies Lviv, Ukraine
}

Article info

Received 13.09.2019

Received in revised form 14.10.2019

Accepted 15.10.2019

Stepan Gzhytskyi National University of Veterinary Medicine and Biotechnologies Lviv, Pekarskaya Str., 50, Lviv, 79010, Ukraine. Tel.: +38-067-370-43-92 E-mail:muniv@ukr.net
Myniv, R.M. (2019). Features of waterproofing of agricultural buildings and structures. Scientific Messenger of Lviv National University of Veterinary Medicine and Biotechnologies. Series: Agricultural sciences, 21(91), 89-93. doi: 10.32718/nvlvet-a9115

High groundwater levels, defects and imperfect drainage systems contribute to the active dampening of stone structures, resulting in their corrosion destruction and accelerated load loss. There are two main sources of capillary pull-up: groundwater level and so-called sprayed water. Analysis of the destruction of stone buildings shows that the major factor in their destruction is the various sources of excessive soaking (up to 50\% of buildings) and, as a consequence, salinization. High groundwater levels, defects and imperfect drainage systems contribute to the active dampening of stone structures, resulting in their corrosion destruction and accelerated load loss. There are two main sources of capillary pull-up: ground water and so-called sprayed water. The humidity decreases in the bottom-up direction, as well as from the middle of the wall to its outer surfaces, which means that the capillary suction of water is in effect. Analysis of the destruction of stone buildings shows that the major factor in their destruction is the various sources of excessive soaking (up to 50\% of buildings) and, as a consequence, salinization. Waterproofing has a huge impact on the durability, comfort, and cost of operating the facilities. The lack of waterproofing or its destruction, as well as the violation of the wet regime, are the cause of many defects in both individual structures and buildings in general, which require considerable cost. In the case of insulation failure or lack thereof, the soil water seeps through the walls and destroys the plaster and masonry from the outside, and after the capillary movement inside the masonry, reaches the inner layer of the plaster. Depending on the degree of threat, the appropriate type of waterproofing should be used. The quality and durability of the waterproofing layer depend on the strength of the surface preparation. Reliable adhesion to the substrate, solid coating and uniform thickness of the waterproofing coating are ensured by quality alignment, cleaning, drying, priming of the insulated surface, as well as careful preparation and execution of joints, touches and seams. To protect the foundations, walls and columns of agricultural buildings and structures from the capillary rise of moisture, we propose to cut off the inter-wall waterproofing and improve the hydrogeological conditions of the site. Waterproofing materials must comply with European standards and be certified by ISO quality management system.

Key words: waterproofing, agricultural buildings and structures.

\section{Особливості гідроізоляції сільськогосподарських будівель і споруд}

\author{
Р.М. Минів
}

Львівський національний університет ветеринарної медицини та біотехнологій імені С.3. Гљицького, м. Львів, Україна

Кам'яні сільськогосподарські будівлі і споруди мають доволі часто значні проблеми внаслідок зволоження стін (фундаментів). Високий рівень трунтових вод, дефекти та недосконалі системи водовідведення сприяють активному зволоженню кам'яних конструкиій, внаслідок чого відбувається їхне корозійне руйнування й пришвидиується втрата несучої здатності. Високий рівень трунтових вод, дефекти та недосконалі системи водовідведення сприяють активному зволоженню кам'яних конструкцій, внаслідок чого відбувається їхнє корозійне руйнування й пришвидшується втрата несучої здатності. Розрізняють два основних джерела капілярного підтягування: з рівня трунтової води і так званої розпорошеної води. Вологість зменшується в напрямку знизу - вверх, а також із середини стіни до ї̈ зовнішніх поверхонь, це означає, щуо діє капілярне підсмоктування води. Аналіз руйнування кам'яних 
будівель засвідчує, щзо основним чинником їхньої руйначії є різноманітні джерела надмірного замокання (до 50\% будівель) $і$, як наслідок, засолення. Гідроізолячія має величезний вплив на довговічність, комфорт, а також витрати на експлуатацію об'єктів. . Відсутність гідроізоляції або ї̈ руйнування, а також порушення вологого режиму є причиною багатьох дефектів як окремих конструкцій, так $і$ будівель загалом, усунення яких вимагає значних витрат. У разі порушення ізолячії або ї̈ відсутності, вода, ияо є в трунті, просочується через стіни і руйнує штукатурку та иегляну кладку із зовнішнього боку, а після капілярного переміщення всередині мурування доходить до внутрішнього шару штукатурки. Залежно від ступеня загрози слід застосовувати відповідний тип гідроізоляції. Якість і довговічність гідроізоляційного шару залежать від міцності підготовки поверхні. Надійне зчеплення з основою, суцільне покриття і рівномірна товщина гідроізолячійного покриття забезпечуються якісним вирівнюванням, очищенням, сушінням, трунтуванням ізольованої поверхні та також ретельною підготовкою й виконанням сполучень, дотиків і швів. Для захисту фундаментів, стін та колон сільськогосподарських будівель і споруд від капілярного підйому вологи ми пропонуємо влаштовувати відсічну внутрішньостінову гідроізолячію та поліпшення гідрогеологічних умов площадки. Матеріали для гідроізоляції повинні відповідати європейським стандартам та бути підтвердженими сертифікатами по системі управління якістю ISO.

Ключові слова: гідроізолячія, сільськогосподарські будівлі і споруди.

\section{Вступ}

Кам'яні сільськогосподарські будівлі і споруди мають доволі часто значні проблеми внаслідок зволоження стін (фундаментів). Високий рівень грунтових вод, дефекти та недосконалі системи водовідведення сприяють активному зволоженню кам'яних конструкцій, внаслідок чого відбувається їхнє корозійне руйнування й пришвидшується втрата несучої здатності (Luchko et al., 1999; Nazarevych \& Luchko, 2010).

Підвальні приміщення будівель оточені вологою землею. Відсутність гідроізоляції або іiї руйнування, а також порушення вологого режиму в підвальних приміщеннях $є$ причиною багатьох дефектів як окремих конструкцій, так і будівель загалом, усунення яких вимагає значних затрат.

В свою чергу відсутність дренажу або його неякісне виконання (замулювання, засмічення) призводить до затоплення підвалів та підмивання фундаментів.

Технічний прогрес і все більш високі вимоги до якості будівельних матеріалів змушують використовувати все більш якісні, ефективні та довговічні ізоляційні матеріали. Ці тенденції можна спостерігати в сільськогосподарському будівництві, так як гідроізоляція має величезний вплив на довговічність, комфорт, а також витрати на експлуатацію об'єктів.

\section{Результати та їх обговорення}

Необхідність виконання гідроізоляції сільськогосподарських будівель і споруд заснована на вимогах, зазначених у будівельному законодавстві, щодо безпечної експлуатації, а також відповідних санітарногігієнічних умов, економії енергії та теплоізоляції будівельних перегородок, що накладає на проектувальника обов'язок урахування впливу зовнішніх факторів на об'єкт протягом усього періоду його використання. Важливим зовнішнім фактором є вплив води, яка представляє загрозу для будівельних об'єктів.

Вода діє на будівлі, як правило, у вигляді опадів: дощу, снігу, туману. При цьому деякі об'єкти особливо уразливі для згубного впливу води протягом усього періоду експлуатації. Залежно від ступеня загрози слід застосовувати відповідний тип гідроізоляції.
Досліджуючи вологий стан стіни, іноді спостерігаємо, що вологість зменшується в напрямку знизу вверх, а також із середини стіни до іiі зовнішніх поверхонь, це означає, що діє капілярне підсмоктування води. Якщо аналізувати загальний стан замокання на розрізах будівлі, то розрізняють два основних джерела капілярного підтягування: 3 рівня грунтової води і так званої розпорошеної води (рис. 1).

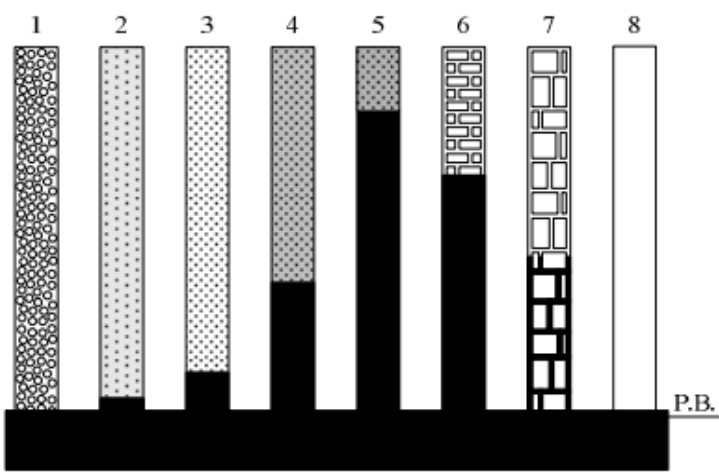

Рис. 1. Капілярне підтягування води в різних матеріалах і будівельних структурах: 1 -гравій, щебінь; 2 - грубий пісок; 3 - дрібний пісок; 4-мул; 5 -спечена глина; 6 - иегляна стіна; 7 - стіна з каменю непористого; 8 -моноліт з непористого (щчільного) каменю

Як правило стіни підвалів виконують 3 цегляного мурування, натурального каменю або бетонних блоків та мають велику кількість швів, i, врешті-решт, створюють проблему щодо водонепроникності стін, що призводить до проникнення в стіни агресивних грунтових та техногенних вод. У разі порушення ізоляції або іiі відсутності, вода, що є в грунті, просочується через стіни і руйнує штукатурку та цегляну кладку із зовнішнього боку, а після капілярного переміщення всередині мурування доходить до внутрішнього шару штукатурки.

Аналіз руйнування кам'яних будівель засвідчує, що основним чинником їхньої руйнації $\epsilon$ різноманітні джерела надмірного замокання (до 50\% будівель) i, як наслідок, засолення.

Основні джерела замокання стін сільськогосподарських будівель і споруд показані на рис. 2. 

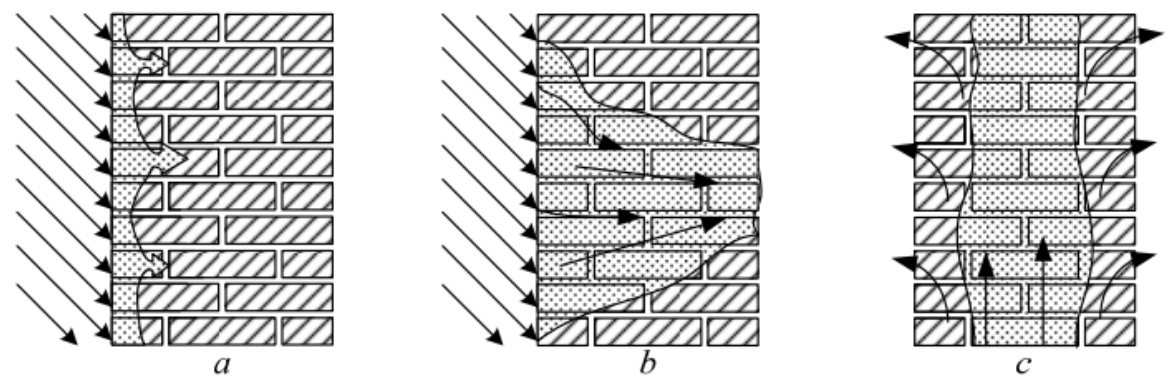

Рис. 2. Види замокання стін сільськогосподарських будівель і споруд:

$a$ - поверхневе зволоження, косі дощі (відбійна вода, конденсаиія тощо - усувається традиційними методами); $b$ - наскрізне замокання (довготривале промокання даху, водостічних труб і інших комунікацій тощо - усувається традиційними методами); c-зволоження (як результат дї капілярного підтягування води з утворенням постійного W\%, та тиску Pbar - const) - усувається методами влаштування горизонтальних гідроізоляиій

Розглянемо основні правила для проектування технології влаштування гідроізоляції в сільськогосподарських будівлях і спорудах старої забудови. Зокрема, під час проектування ремонту будівлі, пошкодженої в результаті замокання ії конструкції та пораження сіллю, слід дотримуватися таких вказівок:

- якщо вологість у стіні зменшується в напрямку знизу вверх, а також із середини стіни до іiї зовнішніх поверхонь, це означає, що діє капілярне підсмоктування води;

- якщо вологість в стіні збільшується в напрямку знизу вверх, або залишається по вертикалі майже незмінною - це означає, що причиною зволоження правдоподібно $є$ гігроскопічні властивості основи (вологість гігроскопічна), що може підтвердити додатковий аналіз на наявність гігроскопічних сполук, правда в окремих випадках це можна віднести до зволоження конденсатною водою (спостерігаємо краплі води на стіні). В цьому випадку слід провести відповідні заміри щодо визначення параметрів середовища (W\% - вологість, $\mathrm{t}$ - температура повітря);

- якщо зволоження збільшується в напрямку від осі стіни до зовнішньої поверхні, то найвірогідніше маємо справу з конденсатним зволоженням;

- оскільки величина поверхневого зволоження стіни може істотно відрізнятися від зволоження всередині стіни, i, отже, іiї не потрібно брати до уваги під час проектування влаштування горизонтальних гідроізоляцій;

- визначення ядра зволоження (величина W\%, Pbar) дає можливість прийняти рішення, яким способом виконувати подачу ін'єкційного матеріалу (гравітаційно чи під тиском) під час влаштування горизонтальної гідроізоляції ін'єкційними методами;

- структура (стан) стіни і несучих елементів $є$ важливими чинниками щодо прийняття рішення із вибору технології влаштування горизонтальної гідроізоляції. Механічні технології можуть бути застосовані в тому випадку, коли дозволяє статика будівлі та при чітко виражених горизонтальних швах кладки і при наявності доступу до поверхонь стін. Найефективніше вони застосовуються при товщині до 510 мм. При застосування ін'єкційних технологій слід використовувати додаткові заходи, щоб уникнути перевитрати ін'єкційного матеріалу.

Найбільш надійними видами гідроізоляції сільськогосподарських будівель і споруд є:

- обмазувальна гідроізоляція;

- проникаюча гідроізоляція;

- ін'єкційна гідроізоляція.

Типи гідроізоляції (гідроізоляційних покриттів) наведено на рис. 3.
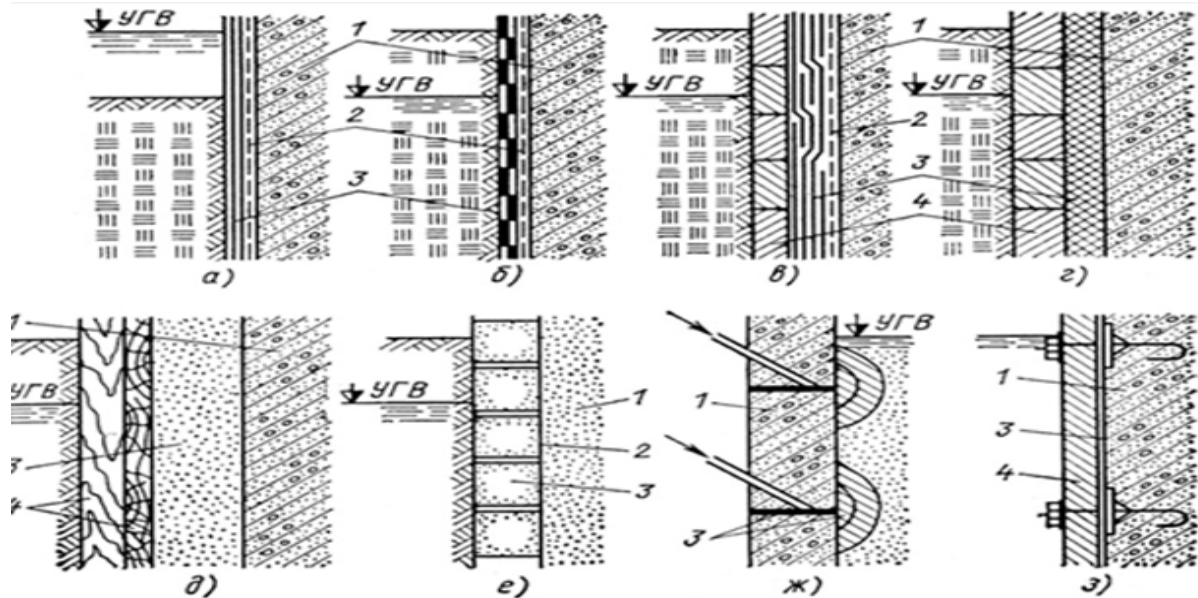

Рис. 3. Типи гідроізоляції (гідроізоляційних покриттів): а) фарбувальна; б) штукатурна; в) обклеювальна; г) лита; д) засипна; е) просочена; ж) ін'єкиійна; з) монтована; 1 - ізолювальна конструкиія; 2 - трунтовка основи; 3 - гідроізолячійне покриття; 4 - захисні огородження 
Обмазувальна гідроізоляція - може застосовуватися для захисту від грунтових вод (зовнішньої сторони будівлі) та від капілярної вологи (всередині приміщень). Існує два основні різновиди обмазувальної гідроізоляції: на цементній основі, на бітумній основі. На сьогоднішньому будівельному ринку існує безліч видів і марок ізоляційних матеріалів обмазувальної гідроізоляції. Вибір матеріалу слід здійснювати, знаючи найбільш важливі і необхідні умови для гідроізоляції фундаменту (Cherevko, 2019).

Обмазувальна гідроізоляція фундаменту повинна забезпечувати:

- $\quad$ повну герметичність і відсутність швів;

- водонепроникність шару;
- $\quad$ достатню товщину покриття;

- $\quad$ міцність і довговічність;

- $\quad$ високу адгезію з оброблюваною поверхнею;

- $\quad$ відсутність усадки.

До матеріалів, що можуть задовольнити всі перераховані вище умови, відносяться бітумні мастики. Вони повинні відповідати високим європейським стандартам та бути підтвердженими сертифікатами по системі управління якістю ISO.

Для гідроізоляції фундаменту на бітумній основі слід застосовувати комплекс матеріалів в залежності від рівня необхідного захисту(табл. 1).

Таблиця 1

Сучасні види обмазувальної гідроізоляції для сільськогосподарських будівель і споруд

\begin{tabular}{|c|c|c|c|}
\hline Вид гідроізоляції & Перший шар & Наступні шари & Переваги \\
\hline $\begin{array}{c}\text { Середня } \\
\text { гідроізоляція }\end{array}$ & $\begin{array}{c}\text { Нанесення } \\
\text { грунтовки } \\
\text { IZOBIT BR в } 1 \\
\text { шар } \\
\end{array}$ & $\begin{array}{l}\text { Нанесення бітумно- } \\
\text { каучукової мастики } \\
\text { IZOBIT DK в } \\
\text { 2-3 шару }\end{array}$ & $\begin{array}{l}\text { - утворює високоякісне еластичне покриття } \\
\text { • шар стійкий до слабких кислот і лугів } \\
\text { • перекриває мікротріщини на поверхні } \\
\text { • можна застосовувати в будь-яку пору року }\end{array}$ \\
\hline $\begin{array}{c}\text { Важка } \\
\text { гідроізоляція }\end{array}$ & $\begin{array}{c}\text { Нанесення } \\
\text { грунтовки } \\
\text { DYSPERBIT } \\
\text { GRUNT в } 1 \text { шар }\end{array}$ & $\begin{array}{c}\text { Нанесення бітумно- } \\
\text { каучукової мастики } \\
\text { STYRBIT 2000-K в } \\
2 \text { шари }\end{array}$ & $\begin{array}{l}\text { - висока адгезія до поверхні } \\
\text { - мастика модифікована синтетичним каучуком } \\
\text { - безпека при контакті з пінополістиролом } \\
\text { • стійкість до дії слабких кислот і лугів } \\
\text { • використовується як клей для пінополістирольних плит } \\
\text { • можна застосовувати в будь-яку пору року } \\
\end{array}$ \\
\hline $\begin{array}{c}\text { Важка } \\
\text { гідроізоляція }\end{array}$ & $\begin{array}{c}\text { Нанесення } \\
\text { грунтовки } \\
\text { DYSPERBIT } \\
\text { GRUNT в } 1 \text { шар }\end{array}$ & $\begin{array}{c}\text { Нанесення бітумно- } \\
\text { каучукової мастики } \\
\text { STYRBIT } 2000 \text { в } 2 \\
\text { шари }\end{array}$ & $\begin{array}{l}\text { - матеріали не містять розчинників } \\
\text { - багатошарова і тиксотропна мастика } \\
\text { - висока адгезія з бетоном, деревом, цегляною кладкою } \\
\text { - можна застосовувати при контакті з пінополістиролом в } \\
\text { якості клею } \\
\text { - стійкість до кислот і лугів у грунті } \\
\text { - не має запаху }\end{array}$ \\
\hline $\begin{array}{l}\text { Важка/середня } \\
\text { гідроізоляція }\end{array}$ & $\begin{array}{c}\text { Зволоження і } \\
\text { насичення по- } \\
\text { верхні водою }\end{array}$ & $\begin{array}{l}\text { Нанесення цемент- } \\
\text { ного розчину } \\
\text { СТРІМСУМІШ } \\
\text { мінімум в } 2 \text { шари }\end{array}$ & $\begin{array}{l}\text { - паропроникність шару } \\
\text { - висока міцність, морозостійкість, водонепроникність, } \\
\text { - зносостійкість } \\
\text { - бронюючі та проникаючі властивості } \\
\text { - працює при позитивному і негативному тиску води } \\
\text { - стійкість до агресивних речовин навколишнього сере- } \\
\text { довища } \\
\text { - може застосовуватися як зовні фундаменту, так і всере- } \\
\text { дині підвального приміщення (при його наявності) } \\
\text { - екологічність матеріалу }\end{array}$ \\
\hline $\begin{array}{c}\text { Важка } \\
\text { гідроізоляція }\end{array}$ & $\begin{array}{c}\text { Зволоження і } \\
\text { насичення по- } \\
\text { верхні водою }\end{array}$ & $\begin{array}{l}\text { Нанесення цемент- } \\
\text { ного розчину ІН- } \\
\text { ФІЛЬТРОН-100 в } 2 \\
\text { шари }\end{array}$ & $\begin{array}{l}\text { - висока проникаюча здатність до } 300 \text { мм } \\
\text { • підвищення показників водонепроникності бетону } \\
\text { - водопроникність при гідростатичному тиску } \\
\text { • не дає усадку } \\
\text { - паропроникність покриття } \\
\text { - висока сульфатостійкість, стійкість до умов агресивного } \\
\text { середовища } \\
\text { - екологічна безпека матеріалу }\end{array}$ \\
\hline
\end{tabular}

Ще одним основним поділом гідроізоляції є відмінність за типом небезпеки (табл. 2). Гідроізоляцію також можна розділити за матеріалами, з яких вона зроблена - так виділяється мінеральна ізоляція, бітумна та пластикова.

Якість і довговічність гідроізоляційного шару залежать від міцності підготовки поверхні. Надійне зчеплення з основою, суцільне покриття і рівномірна товщина гідроізоляційного покриття забезпечуються якісним вирівнюванням, очищенням та сушінням. За необхідності проводять грунтування ізольованої поверхні, а також ретельну підготовку і виконання сполучень, дотиків і швів. 
Таблиця 2

Гідроізоляції за типом небезпеки

\begin{tabular}{|c|c|}
\hline Тип & Характеристика \\
\hline Легкий & $\begin{array}{l}\text { Ізоляцію застосовують для захисту споруд від проникнення вологи у бічному напрямку. Її не слід засто- } \\
\text { совувати для захисту від води та прямих опадів(наприклад, у разі покрівлі) або для горизонтальних пере- } \\
\text { городок (ізоляції терас, водопропускних труб, підземних резервуарів тощо). Таку ізоляцію застосовують } \\
\text { на об'єктах, розташованих вище рівня грунтових вод }\end{array}$ \\
\hline Середній & $\begin{array}{l}\text { Ізоляцію застосовують для захисту будівлі від вологи, прямих опадів, у разі горизонтальних і вертикаль- } \\
\text { них перегородок. Ізоляцію цього типу не слід використовувати для захисту споруд від води під тиском. } \\
\text { Винятки з цього правила можуть бути випадки, коли тиск води є тимчасове або коли повна герметич- } \\
\text { ність не потрібно. Ізоляція середнього типу потрібна найчастіше тоді, коли трохи нижче рівня закладен- } \\
\text { ня фундаменту знаходиться грунт пропускає воду, а на рівні фундаменту грунт є водонепроникним }\end{array}$ \\
\hline Важкий & $\begin{array}{l}\text { Ізоляцію важкого типу застосовують для захисту будівельного об’єкту від води під тиском, коли знахо- } \\
\text { диться нижче рівня грунтових вод, а також у разі важких грунтів, на яких після дощу довго залишаються } \\
\text { калюжі з-за складного проходження води в грунт }\end{array}$ \\
\hline
\end{tabular}

Свіжонанесену гідроізоляцію необхідно захистити від попадання прямих сонячних променів та від потрапляння атмосферних опадів протягом 5-6 год від моменту нанесення. Схеми влаштування (аплікації) вертикальних блокад сільськогосподарських будівель і споруд наведені на рис. 4.
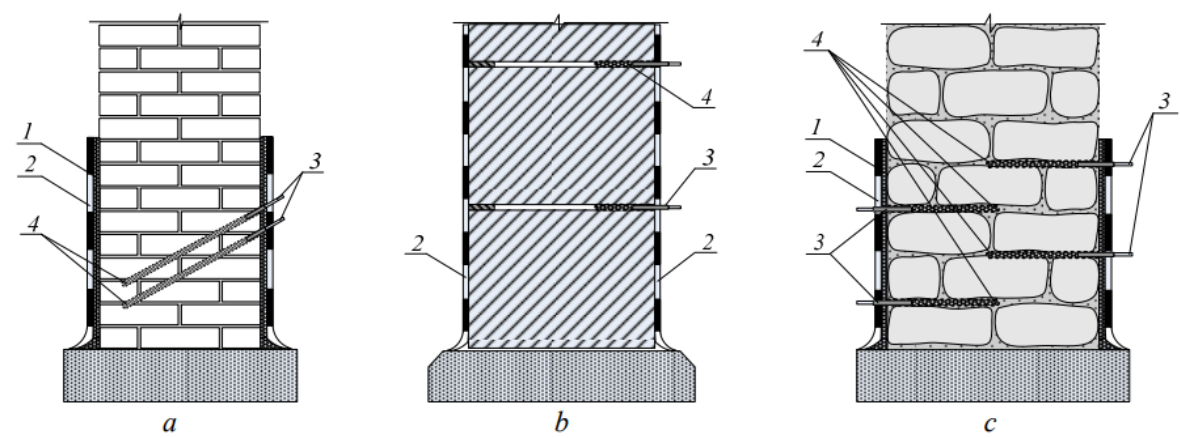

Рис. 4. Схеми аплікацій вертикальних блокад сільськогосподарських будівель і споруд під час влаштування горизонтальних гідроізоляцій на поверхнях стін з різних матеріалів

$a$ - цегляна стіна; $b$ - стіна із фундаментних блоків; c - бутова стіна; 1 - вирівнювальна пішано-цементна штукатурка; 2 - полімериементний розчин (мінеральна гідроізоляція); 3 - пакер (штуцер); 4- шпур (отвори Ø 12-18 мм)

Для захисту фундаментів, стін та колон сільськогосподарських будівель і споруд від капілярного підйому вологи ми пропонуємо влаштовувати відсічну внутрішньостінову гідроізоляцію та поліпшення гідрогеологічних умов площадки. В попередньо пробурені в цегляній кладці шпури ø18 мм ін'єктується гідрофобізіруюча рідина. Крок шпурів влапштовується виходячи 3 необхідного розрахунку повного перекриття капілярів гідрофобізіруючою рідиною. Також улаштовувалась вертикальна обмащувальна гідроізоляція та сануюча штукатурка для нейтралізації впливу шкідливих для цегли солей.

\section{Висновки}

Гідроізоляція - важливий чинник забезпечення довготривалої експлуатації сільськогосподарських будівель і споруд та підвищення їхньої довговічності. Якісне виконання робіт з облаштування всіх видів гідроізоляції, що повинно відповідати сучасним вимогам якості, дозволить убезпечити конструкції сільськогосподарських будівель і споруд від проникнення та шкідливого впливу води, хімічно агресивних рідин, стічних вод тощо, адже головне в гідроізоляції не матеріали, а сумлінне та надійне виконання робіт.

\section{References}

Cherevko, Y. (2019). Materialy dlia hidroizoliatsii fundamentu. Elektronnyi resurs: https://sanpol.ua/ ua/library/tehnologii-gidroizolyatsii/hidroizolyaciafundamenta (in Ukrainian).

Cherevko, Y. (2019). Vydy hidroizoliatsii. Elektronnyi resurs: https://sanpol.ua/ua/library/tehnologiigidroizolyatsii/vidy-gidroizolyatsii (in Ukrainian).

Luchko, Y.I., Hlahola, I.I., \& Nazarevych, B.L. (1999). Metody pidvyshchennia koroziinoi stiikosti ta dovhovichnosti betonnykh ta zalizobetonnykh konstruktsii i sporud. Lviv: Kameniar (in Ukrainian).

Mohylnychenko, V., Korepanova, N., \& Ovcharenko, B. (2019). Hidroizoliatsiia zakhysnykh sporud tsyvilnoho zakhystu. Elektronnyi resurs: https://nsplus.com.ua/2019/06/12/gidroizolyatsiya-zahysnyhsporud-tsyvilnogo-zahystu (in Ukrainian).

Nazarevych, B.L., \& Luchko, Y.I. (2010). Tekhnolohiia vlashtuvannia horyzontalnoi hidroizoliatsii V budivliakh staroi zabudovy. Naukovo-tekhnichnyi zbirnyk "Suchasni tekhnolohii, materialy i konstruktsii v budivnytstvi", 77-89. http://ir.lib.vntu.edu.ua/ bitstream/handle/123456789/4245/43.pdf?sequence (in Ukrainian). 